\title{
COMPLEX TECHNOLOGICAL AND BIOLOGICAL RESEARCH OF SOLUTIONS FOR PERITONEAL DIALYSIS
}

\author{
NATALIIA HUDZ ${ }^{1}$, RAISA KORYTNIUK ${ }^{2}$, LILIIA VYSHNEVSKA ${ }^{3}$, PIOTR P. WIECZOREK ${ }^{4}$
}

1Department of Drug Technology and Biopharmacy, Danylo Halytsky Lviv National Medical University, Lviv, Ukraine, ${ }^{2}$ Department of Pharmaceutical Technology and Biopharmacy, Shupyk National Medical Academy of Postgraduate Education, Kyiv, Ukraine, ${ }^{3}$ Department of Drug Technology, National Pharmaceutical University, Kharkiv, Ukraine, ${ }^{4}$ Department of Analytical and Ecological Chemistry, University of Opole, Opole, Poland

Email: natali_gudz@ukr.net

Received: 17 Jan 2018, Revised and Accepted: 24 May 2018

\section{ABSTRACT}

Objective: The purpose of our work was to conduct technological, analytical, and biological investigations and stability studies of peritoneal dialysis (PD) solutions containing glucose and sodium lactate in single-chamber containers.

Methods: Different formulations of PD solutions were prepared and sterilized at a temperature of $121{ }^{\circ} \mathrm{C}$ during $15 \mathrm{~m}$. UV-spectrophotometric determination was performed using purified water as a blank. The spectra of the solutions were run in the range of 220 to $400 \mathrm{~nm}$ for the identification of an absorption maximum $\left(\lambda_{\max }\right)$ and measuring the absorbance at $228-230 \mathrm{~nm}$ and $\lambda_{\max }$ before and after heat sterilization. $\lambda_{\max }$ of the most PD solutions after sterilization was found in the range of 273 to $281 \mathrm{~nm}$. The potentiometric determination was done for $\mathrm{pH}$ measuring PD solutions before and after sterilization. Alternative analytical procedure of direct argent metric method was employed for fast measuring content of chloride ions. Viability of Vero cells was evaluated using 3-[4, 5-dimethylthiazol-2-yl]-2,5-diphenyltetrazolium bromide (MTT) test, neutral red (NR) uptake assay, and sulforhodamine B (SRB) test.

Results: The results showed that the absorbance of the most laboratory batches of PD solutions augments significantly with increasing an autoclave heating time to the sterilization temperature and time of its cooling after sterilization. The longer these parameters, the higher is the absorbance at 228-230 and 273-281 nm indicating 3,4-dideoxyglucoson-3-en (3,4-DGE) and 5-hydroxymethylfurfural (5-HMF) contents, respectively. Glucose degradation is practically absent at short terms of heating and cooling an autoclave while sterilized samples are preserved sterile. Stability studies showed a significant decrease in the absorbance at 228-230 nm during storage with the achievement of a nadir and the following weak increase; an elevation or decrease in the absorption maximum; a substantial decline in the $\mathrm{pH}$ of the solution after sterilization and an insignificant $\mathrm{pH}$ decrease during storage. The viability of kidney cells was the highest in the SRB test and the lowest one was in the MTT test.

Conclusion: The influence of sterilization regimes on the quality of conventional PD solutions and their stability during storage were studied. The highest cytotoxicity was detected in the MTT test, and the lowest one was done in the SRB test, indicating the largest vulnerability of mitochondria under the influence of PD solutions compared to the membranes permeability, functioning of kidney cell lysosomes and the ability of cells to synthesize proteins. Our studies could be useful in the context of planning development of PD solutions with the purpose of authorization and domestic manufacture of these solutions in low-and-middle-income countries.

Keywords: Peritoneal dialysis, Prodution, 5-hydroxymethylfurfural, 3,4-dideoxyglucoson-3-en, Cell viability, Kidneys cells, Vero cells

(C) 2018 The Authors. Published by Innovare Academic Sciences Pvt Ltd. This is an open access article under the CC BY license (http://creativecommons.org/licenses/by/4.0/) DOI: http://dx.doi.org/10.22159/ijap.2018v10i4.24823

\section{INTRODUCTION}

Chronic kidney disease (CKD) is a worldwide public health problem caused by diabetes, hypertension, obesity, smoking, aging and other diseases. CKD is associated with increased incidences of mortality, morbidity and reduced quality of life because of numerous complications of CKD (cardiovascular diseases, anemia, etc.). According to the World Health Organization data, diseases of kidneys and urinary tract contribute to approximately 850000 deaths every year. CKD occupies the 12th leading cause of death and 17th leading cause of disability in the world. The prevalence of CKD in the United States of America ranges from $1.5 \%$ to $15.6 \%$. In India, majority of the CKD patients belong to the younger population compared to other countries. Progression of CKD leads to end-stage renal disease (ESRD). Patients with ESRD require renal replacement therapy (RRT) (haemodialysis, peritoneal dialysis (PD) and kidney transplantation) [1-3]. Treatment of ESRD is cost prohibitive for most countries. The incidence of ESRD in India is 226 per million population and it is expected that nearly 220000 new patients will be added to general amounts of patients with ESRD every year [3]. PD is an essential lifesustained treatment modality of RRT. Approximately $10 \%$ of dialysis population is treated with PD. The same fig. is observed in India. The prevalence of PD patients increases in both developed and developing countries [1-3]. PD is widely documented to cost less to health care systems in the world. Because of fewer infrastructure requirements, $\mathrm{PD}$ is more likely to promote equity in dialysis delivery. Most countries, which deliver dialysis through a public delivery mechanism, employ PD as a first choice [3].

PD procedure uses sterile solutions in a total daily amount of up to 8-40 litres depending on PD modality. Solutions containing dextrose and sodium lactate are most frequently used, $\mathrm{pH}$ of which is approximately 5.0-5.5 [4-7, 10]. Steam sterilization is a method of choice in order to ensure the sterility of such solutions as other methods such as ionizing radiation, pulsed ultraviolet light, filtration, and ohmic heat have prohibitive limitations or have not been adequately studied for use in the PD solutions manufacture [9]. However, during steam sterilization and subsequent storage glucose degradation products (GDPs) with cytotoxic properties are formed, including formaldehyde, acetaldehyde, methylglyoxal $(2-14 \mu \mathrm{M})$, glyoxal, low molecular acids, 3-deoxyglycosone (3-DG) (325-425 $\mu \mathrm{M}), 3$-deoxyaldose-2-en, 3,4-dideoxyglucoson-3-ene (3,4-DGE) (25$125 \mu \mathrm{M})$, 5-hydroxymethylfurfural (5-HMF), and other compounds. Glucose degradation is a very complex process as there are a lot of degradation routes of glucose and GDPs [6, 7, 10-12]. Studies of the last $30 \mathrm{y}$ indicate their adverse effects on the peritoneum and the whole organism. 3,4-DGE and traditional solutions with high levels of GDPs induce the apoptosis of mesothelial and renal cells in vitro by oligomerization of Bax at mitochondria and activating caspase, neutrophils and peripheral blood mononuclear cells [4, 12]. GDPs bind to reactive amino acid side chains of proteins that leads to the formation of advanced glycation end products $[8,11]$. Solutions with 
low glucose and GDPs concentrations are associated with higher effluent levels of cancer antigen 125 (CA125), probably reflecting a higher mesothelium cells mass [13]. The use of biocompatible solutions with neutral $\mathrm{pH}$ and low GDPs level leads to less peritoneal injury in patients, the better preservation of residual renal function $[8,10,12]$. In recent decades, the attention of scientists has been focused on the development of more biocompatible solutions and/or the use of more advanced sterilization techniques that contribute to less glucose degradation [7-9, 13]. In this case, the elaboration of the composition of PD solutions is often carried out in a combination with a biological research, namely the study of cells viability in the presence of PD solutions $[6,7,10,11]$. While discussions are conducted about benefits and disadvantages of novel PD solutions of the second generation in the whole world, it is rational to produce traditional (conventional) PD solutions with low GDPs content in cost-conscious countries to reduce direct out-of-pocket expenditures and continue long-term treatment of patients suffering from ESRD $[7,8,13,14]$. Nevertheless, to the best of our knowledge, scientific papers do not provide information for production methods and long-term stability of any PD solutions, the interrelation of cells viability determined with different procedures and studies of the viability of monkey kidney cells under influence of PD solutions.

\section{MATERIALS AND METHODS}

\section{Materials}

The objects of the research were solutions for PD with a content of lactate ions of 35 and $40 \mathrm{mmol} / \mathrm{l}$ and $1.5 \%, 2.5$ and $4.25 \%$ of glucose monohydrate in glass and polyvinylchloride (PVC) containers. The composition of the tested solutions is shown in table 1.

Table 1: Composition of the tested solutions

\begin{tabular}{|c|c|c|c|c|c|c|c|}
\hline \multirow[t]{2}{*}{ Sample number } & \multicolumn{5}{|c|}{ Ions concentration, $\mathrm{mmol} / \mathrm{l}$} & \multirow[t]{2}{*}{ Glucose monohydrate concentration, $\mathrm{g} / \mathrm{l}$} & \multirow[t]{2}{*}{ Packaging } \\
\hline & $\mathrm{Na}^{+}$ & $\mathrm{Ca}^{2+}$ & $\mathrm{Mg}^{2+}$ & $\mathrm{Cl}^{-}$ & $\mathrm{CH}_{3} \mathrm{CH}(\mathrm{OH}) \mathrm{COO}^{-}$ & & \\
\hline 0 & 154 & - & - & 154 & - & - & glass \\
\hline $1(10413)$ & 132 & 1.25 & 0.25 & 95 & 40 & 15.0 & $-/ /-$ \\
\hline $2(20413)$ & 132 & 1.25 & 0.25 & 95 & 40 & 42.5 & $-/ /-$ \\
\hline $3(30513)$ & 132 & 1.25 & 0.25 & 95 & 40 & 15.0 & $-/ /-$ \\
\hline $4(40513)$ & 132 & 1.25 & 0.25 & 95 & 40 & 42.5 & $-/ /-$ \\
\hline $5(10415)$ & 132 & 1.25 & 0.25 & 100 & 35 & 15.0 & $-/ /-$ \\
\hline $6(20415)$ & 132 & 1.25 & 0.25 & 100 & 35 & 25.0 & $-/ /-$ \\
\hline $7(30415)$ & 132 & 1.25 & 0.25 & 100 & 35 & 42.5 & $-/ /-$ \\
\hline $8(21116)$ & 132 & 1.25 & 0.25 & 95 & 40 & 42.5 & PVC \\
\hline $9(10117)$ & 132 & 1.25 & 0.25 & 95 & 40 & 25.0 & $-/ /-$ \\
\hline
\end{tabular}

Sterilization of the PD solutions was carried out at $121^{\circ} \mathrm{C}$ for $15 \mathrm{~min}$ in accordance with the regimes presented in table 2.

Table 2: Sterilization regimes of the tested PD solutions

\begin{tabular}{|c|c|c|c|c|c|}
\hline Sample & $\begin{array}{l}\text { Heating time of } \\
\text { the autoclave to } \\
121^{\circ} \mathrm{C}, \mathrm{min}\end{array}$ & $\begin{array}{l}\text { Sterilization } \\
\text { time at } 121^{\circ} \mathrm{C} \text {, } \\
\text { min }\end{array}$ & $\begin{array}{l}\text { Total time of pressure drop to } \\
0 \text { atm and staying containers } \\
\text { in the autoclave until its } \\
\text { opening, min }\end{array}$ & $\begin{array}{l}\text { Time of staying } \\
\text { containers in an } \\
\text { autoclave after its } \\
\text { opening, min }\end{array}$ & Remark \\
\hline $\begin{array}{l}1(10413) \\
2(20413)\end{array}$ & 7 & 15 & 14 & - & $\begin{array}{l}\text { simultaneous sterilization } \\
\text { of the samples in one } \\
\text { autoclave }\end{array}$ \\
\hline $\begin{array}{l}3(30513) \\
4(40513)\end{array}$ & 20 & 15 & 16 & 33 & $-/ /-$ \\
\hline $5(10415)$ & 7 & 15 & 24 & 9 & $\begin{array}{l}\text { samples } 5 \text { and } 7 \text { were } \\
\text { sterilized in the same }\end{array}$ \\
\hline $6(20415)$ & 5 & 15 & 11 & 3 & $\begin{array}{l}\text { autoclave as the different } \\
\text { loadings }\end{array}$ \\
\hline $7(30415)$ & 13 & 15 & 18 & 9 & - \\
\hline
\end{tabular}

\section{Methods}

\section{Determination of chloride ions}

Measuring real concentration of chloride ions was carrying out according to the following alternative validated procedure. $10 \mathrm{ml}$ of a PD solution ( $5 \mathrm{ml}$ of an isotonic solution of sodium chloride) are titrated with $0.1 \mathrm{M}$ solution of silver nitrate using $0.8 \mathrm{ml}$ of potassium chromate solution as indicator $(0.4 \mathrm{ml}$ of potassium chromate solution for an isotonic solution of sodium chloride) to an orangeyellow colour, stirring constantly. The content of chloride ions should be from 95 to $105 \%$ of the stated amount [20].

Each $1 \mathrm{ml}$ of $0.1 \mathrm{M}$ silver nitrate is equivalent to $3.545 \mathrm{mg}$ of $\mathrm{Cl}^{-}$. The content of chloride ions $\left(\mathrm{X}_{1}\right)$, in $\mathrm{mmol} / \mathrm{l}$, in a PD solution, is calculated according to the following formula:

$$
X_{1}=V_{1} \bullet K \bullet 3.545 \bullet 1000: 10: 35.45=V_{1} \bullet K \bullet 10 \text {. }
$$

The content of chloride ions $\left(\mathrm{X}_{2}\right)$, in $\mathrm{mmol} / \mathrm{l}$, in an isotonic solution of sodium chloride, is calculated according to the following formula:

$$
X_{2}=V_{2} \bullet K \bullet 3.545 \bullet 1000: 5: 35.45=V_{2} \bullet K \bullet 20,
$$

where: $V_{1}$ and $V_{2}$-volumes of $0,1 \mathrm{M}$ solution of silver nitrate spent on titration of a tested PD solution and isotonic solution of sodium chloride, $\mathrm{ml}$, respectively; $\mathrm{K}-\mathrm{a}$ correction coefficient to the molarity of $0.1 \mathrm{M}$ solution of silver nitrate.

\section{Determination of glucose degradation}

The process of glucose degradation was estimated by changing the values of $\mathrm{pH}$ and the absorbance at $228-230 \mathrm{~nm}$ and the wavelength of maximum absorption at about $279 \mathrm{~nm}$ before and after sterilization and during storage. Spectrophotometric analysis was carried out using UV-Visible spectrophotometers with $10 \mathrm{~mm}$ path length quartz cells.

\section{Measuring solutions pH}

The $\mathrm{pH}$ of the tested PD solutions was measured at a temperature range of $20^{\circ} \mathrm{C}$ to $25{ }^{\circ} \mathrm{C}$. The limits of the monograph of the British Pharmacopeia for PD solutions are 5.0-6.5.

\section{Analytical equipment used in analytical studies}

Analytical equipment was the following: pH-meters: "pH-150 M" (Gomel Plant of Measuring Instruments, Belarus) (1), pH-410 
(Aquilon, Russian Federation) (2), "Sartorius AG" (Germany), pHS3E (China) (3), Seven Compact $\mathrm{pH} /$ ion (Germany) (4); spectrophotometers: "Specord 210 Plus" (5), "Optizen POP" (Mecasys Co. Ltd., Korea) (6), "Photometry Hitachi U-2810" (Hitachi HighTechnologies Corporation, Japan) (7), and "Carry 100" (Agilent Technologies, Australia) (8).

\section{Estimation of cytotoxic action of PD solutions}

Cells of the kidney of an African green monkey (Vero cells), obtained from the Institute of Microbiology and Virology of National Academy of Sciences of Ukraine (Kyiv), were the object of the study in vitro. Special equipment used for cell cultivation was the following: laminar box, binocular microscope, thermostat with a humidified atmosphere $\left(5 \% \mathrm{CO}_{2}\right.$ and $95 \%$ air), a plate rotary centrifuge, 96-well absorbance reader (Tecan's Sunrise absorbance microplate reader), single-dose and multichannel variable-volume dispensers from 1 to $1000 \mu \mathrm{l}$, a Goryaev's camera, electronics laboratory scale, a pHmeter. Cells were incubated in Roswell Park Memorial Institute (RPMI) medium 1640 in a humidified atmosphere of $5 \% \mathrm{CO}_{2}$ and $95 \%$ air at $37^{\circ} \mathrm{C}$. This medium contained $4 \mathrm{mmol}$ of L-glutamine, $10 \%$ of fetal bovine serum and $40 \mu \mathrm{g} / \mathrm{ml}$ of gentamicin. The medium was changed every $2 \mathrm{~d}$. During the experiment, $100 \mu \mathrm{l}$ of a suspension of cells at a density of $1 \times 10^{5}$ cells per ml was placed into each well of a 96-well plate. The cells were incubated for cells adhesion and monolayer formation in the wells during $24 \mathrm{~h}$. Then, $100 \mu \mathrm{l}$ of each PD solution and $0.9 \%$ solution of sodium chloride were added in the wells in two replicates. $100 \mu \mathrm{l}$ of the culture medium was added to the control wells. The plates were incubated in the incubator with $5 \% \mathrm{CO}_{2}$ at $37^{\circ} \mathrm{C}$ for $24 \mathrm{~h}$.

\section{MTT test}

The MTT test is based on the ability of the mitochondrial membrane enzyme, succinate dehydrogenase, and NAD(P)H-dependent cellular oxidoreductase enzyme to reduce the yellow salt of 3-[4,5dimethylthiazol-2-yl]-2,5-diphenyltetrazolium bromide (MTT) to purple insoluble crystals formed in the cytoplasm of living cells [11, 15-17]. $0.5 \%$ solution of MTT (Sigma) (Hanks's solution as a solvent) was filtered through a sterile cellulose acetate membrane filter. After the incubation, $10 \mu \mathrm{l}$ of MTT solution was injected into each well. Then incubation was conducted during $3 \mathrm{~h}$ in a $\mathrm{CO}_{2}$-incubator. After this incubation, the plates were centrifuged at a rate of $1500 \mathrm{rpm}$ for $5 \mathrm{~min}$, and then a supernatant fluid was removed from the wells and $50 \mu \mathrm{l}$ of dimethyl sulfoxide (Sigma) was added to each well to dissolve the formazan crystals. The plates were kept at room temperature for $30 \mathrm{~min}$, and then the absorbance of the contents of all the wells was determined at a wavelength of $540 \mathrm{~nm}$ using Tecan's Sunrise absorbance microplate reader (Austria).

\section{SRB test}

The test with sulforhodamine B is based on the ability of this anionic dye to interact with cell proteins that allows determining the cells ability to synthesize proteins and the degree of cells proliferation.
After the incubation, the culture medium was carefully removed from each well and the wells were washed with a warm phosphate buffer solution to remove proteins from the culture medium that could significantly affect the results of an experiment with sulforhodamine B. Then, $10 \%$ solution of trichloroacetic acid in a saline solution was added for fixation of the cells and maintained in a refrigerator at a temperature of $4{ }^{\circ} \mathrm{C}$ for $1 \mathrm{~h}$. Upon completion of the fixation, the plates were carefully washed with running water and dried on a filter paper. $0.4 \%$ solution of sulforhodamine B was added to the wells. The plates were kept at room temperature for 60 min. The wells were washed with $1 \%$ aqueous acetic acid solution three times with the purpose of removing the dye.

Then, $100 \mu \mathrm{l}$ of $10 \mathrm{mmol}$ of the Trise-base solution was added to each well to dissolve the dye. The wells are held on a shaker at a speed of approximately 250 rotations per min. The absorbance of the contents of the wells was determined at a wavelength of $540 \mathrm{~nm}$ using the Tecan's Sunrise absorbance microplate reader (Austria).

\section{NR test}

NR test is based on the ability of living cells to absorb and accumulate neutral red dye in lysosomes [18]. After the incubation, the medium was carefully removed from each well. Cells were washed with $150 \mu \mathrm{l}$ of warm buffer solution. Then, $100 \mu \mathrm{l}$ of NR solution was added to each well. Incubation was carried out in a thermostat for $3 \mathrm{~h}$. After the incubation, the NR solution was removed and the wells were washed by adding $150 \mu \mathrm{l}$ of phosphate buffer. After removing the buffer, $150 \mu \mathrm{l}$ of extraction solution was added to the well and the plate was gently shaken on the plate shaker for $10 \mathrm{~min}$. The absorbance of the wells contents was determined at a wavelength of $540 \mathrm{~nm}$ using the Tecan's Sunrise absorbance microplate reader (Austria).

In all the cases the cells viability was calculated to the following formula:

$\%$ viability = Viabilitytested $/$ Viabilitymedium x 100\%, where

$\%$ viability-the number of viable cells in \%,

Viabilitymedium-the absorbance in the wells with the medium,

Viabilitytested-the absorbance in the wells with the tested samples.

\section{Characteristic of date correlation}

For characterization of a correlation coefficient ( $r$ ) between the two magnitudes, Achim Bühl and Peter Zöfel's classification was used: to 0.2 -a very weak correlation, to 0.5 is a weak one, to 0.7 is a medium one, to 0.9 is a high one, and over 0.9 is very high correlation [19].

\section{RESULTS AND DISCUSSION}

Our technological research indicates a significant effect of the sterilization regime on the content of GDPs in the PD solutions. The results of the technological and analytical studies of samples of PD solutions are presented in table 3 .

Table 3: Analytical parameters of the tested PD solutions

\begin{tabular}{|c|c|c|c|c|c|c|}
\hline \multirow{2}{*}{$\begin{array}{l}\text { pH before } \\
\text { sterilization, } \\
\text { mean } \pm \mathrm{SD}^{*}\end{array}$} & \multirow{2}{*}{$\begin{array}{l}\text { pH after } \\
\text { sterilization, } \\
\text { mean } \pm \text { SD }^{* *}\end{array}$} & \multirow[t]{2}{*}{$\Delta \mathrm{pH}$} & \multicolumn{4}{|c|}{$\begin{array}{l}\text { Absorbance (mean for } 2-3 \text { containers) } \\
\text { before sterilization after sterilization }\end{array}$} \\
\hline & & & at $228-230 \mathrm{~nm}$ & at $273-286 \mathrm{~nm}$ & at $228-230 \mathrm{~nm}$ & at $\lambda_{\max }$ \\
\hline \multicolumn{7}{|c|}{ sample 1(10413) } \\
\hline $6.49^{1}$ & $6.38^{1}$ & 0.11 & - & - & $0.326-0.242^{8}$ & $\begin{array}{l}0.033-0.027 \text { at } 273-286 \\
\mathrm{~nm}, \max \mathrm{n} / \mathrm{d}\end{array}$ \\
\hline $6.18^{1}$ & $6.19^{1}$ & -0.01 & $\begin{array}{l}0.278 \text { at } \\
228 \mathrm{~nm}\end{array}$ & $\begin{array}{l}0.006 \text { at } \\
284 \mathrm{~nm}\end{array}$ & $0.301-0.218^{8}$ & $\begin{array}{l}0.024-0.021 \text { at } 273-286 \\
\mathrm{~nm}, \max \mathrm{n} / \mathrm{d}\end{array}$ \\
\hline \multirow[t]{2}{*}{$5.71^{1}$} & $5.73^{1}$ & -0.02 & $\begin{array}{l}0.291 \text { at } \\
228 \mathrm{~nm}\end{array}$ & $\begin{array}{l}0.005 \mathrm{at} \\
284 \mathrm{~nm}\end{array}$ & $0.302-0.219^{8}$ & $\begin{array}{l}0.017-0.015 \text { at } 273-286 \\
\mathrm{~nm}, \max \mathrm{n} / \mathrm{d}\end{array}$ \\
\hline & $\begin{array}{l}\text { in } 50 \mathrm{mo} \\
5.77^{1} \\
5.63^{2}\end{array}$ & -0.04 & - & - & $0.340-0.248^{6}$ & $\begin{array}{l}0.043-0.034 \text { at } 273-286 \\
\mathrm{~nm}, \max \mathrm{n} / \mathrm{d}\end{array}$ \\
\hline $5.42^{1}$ & $5.44^{1}$ & -0.02 & $\begin{array}{l}0.327 \text { at } \\
228 \mathrm{~nm}\end{array}$ & - & $0.301-0.217^{8}$ & $\begin{array}{l}0.016-0.015 \text { at } 273-286 \\
\mathrm{~nm}, \max \mathrm{n} / \mathrm{d}\end{array}$ \\
\hline $5.23^{1}$ & $5.23^{1}$ & 0 & $\begin{array}{l}0.296 \text { at } \\
228 \mathrm{~nm}\end{array}$ & $\begin{array}{l}0.010 \text { at } \\
284 \mathrm{~nm}\end{array}$ & $0.319-0.233^{8}$ & $\begin{array}{l}0.018-0.015 \text { at } 273-286 \\
\mathrm{~nm}, \max \mathrm{n} / \mathrm{d}\end{array}$ \\
\hline
\end{tabular}




\begin{tabular}{|c|c|c|c|c|c|c|}
\hline \multicolumn{7}{|c|}{ sample 3(30513) } \\
\hline $6.64^{1}$ & $5.63^{1}$ & 1.01 & $0.308-0.221$ & $0.056-0.061$ & $1.310-1.193^{8}$ & $0.744, \lambda_{\max }=273.0$ \\
\hline $6.21^{1}$ & $5.57^{1}$ & 0.64 & $0.279-0.195$ & $0.026-0.022$ & $1.399-1.283^{8}$ & $0.781, \lambda_{\max }=275.0$ \\
\hline \multirow[t]{6}{*}{$5.72^{1}$} & $5.50^{1}$ & 0.22 & - & - & $1.161-1.053^{8}$ & $0.573, \lambda_{\max }=276.0$ \\
\hline & in $46 \mathrm{mo}$ & & & & & \\
\hline & $5.22^{4}$ & 0.28 & - & - & $0.771-0.674^{7}$ & $0.576, \lambda_{\max }=276.3$ \\
\hline & in $50 \mathrm{mo}$ & & & & & \\
\hline & 5.441 & -0.22 & - & - & $0.877-0.765^{6}$ & $0.686, \lambda_{\max }=276.0$ \\
\hline & $5.28^{2}$ & & & & & \\
\hline $5.40^{1}$ & $5.35^{1}$ & 0.05 & $0.296-0.210$ & $0.022-0.018$ & $1.019-0.916^{8}$ & $0.454, \lambda_{\max }=280.0$ \\
\hline $5.20^{1}$ & 5.17 & 0.03 & $0.290-0.205$ & $0.011-0.008$ & $1.032-0.928^{8}$ & $0.581, \lambda_{\max }=281.0$ \\
\hline \multicolumn{7}{|c|}{ sample 2(20413) } \\
\hline \multirow[t]{4}{*}{$6.54^{1}$} & $5.48^{1}$ & 1.06 & 0.305 at & 0.024 at & $1.509-1.390^{8}$ & $0.854, \lambda_{\max }=275.0$ \\
\hline & & & $228 \mathrm{~nm}$ & $284 \mathrm{~nm}$ & & \\
\hline & in $44 \mathrm{mo}$ & & & & & \\
\hline & 5.35 & 0.13 & - & - & $1.264-1.147^{7}$ & $1.156, \lambda_{\max }=275.5$ \\
\hline \multirow[t]{4}{*}{$6.12^{1}$} & $5.50^{1}$ & 0.62 & 0.284 at & 0.014 at & $1.375-1.261^{8}$ & $0.706, \lambda_{\max }=274.0$ \\
\hline & & & $228 \mathrm{~nm}$ & $284 \mathrm{~nm}$ & & \\
\hline & in $44 \mathrm{mo}$ & & & & & \\
\hline & 5.341 & 0.16 & - & - & $1.138-1.029^{7}$ & $0.961, \lambda_{\max }=275.3$ \\
\hline \multirow[t]{7}{*}{$5.73^{1}$} & 5.43 & 0.30 & 0.335 at & 0.034 at & $1.283-1.172^{8}$ & $0.621, \lambda_{\max }=275.0$ \\
\hline & & & $228 \mathrm{~nm}$ & $284 \mathrm{~nm}$ & & \\
\hline & in $44 \mathrm{mo}$ & & & & & \\
\hline & 5.35 & 0.08 & - & - & $0.965-0.864^{7}$ & $0.802, \lambda_{\max }=276.6$ \\
\hline & in $50 \mathrm{mo}$ & & & & & \\
\hline & $5.37^{1}$ & -0.02 & - & - & $1.081-0.961^{6}$ & $0.923, \lambda_{\max }=277.0$ \\
\hline & $5.20^{2}$ & & & & & \\
\hline \multirow[t]{4}{*}{$5.42^{1}$} & $5.30^{1}$ & 0.12 & 0.340 at & 0.033 at & $1.147-1.042^{8}$ & $0.541, \lambda_{\max }=278$ \\
\hline & & & $228 \mathrm{~nm}$ & $284 \mathrm{~nm}$ & & \\
\hline & in $44 \mathrm{mo}$ & & & & & \\
\hline & $5.26^{1}$ & 0.04 & - & - & $0.931-0.833^{7}$ & $0.934, \lambda_{\max }=279.3$ \\
\hline \multirow[t]{4}{*}{$5.24^{1}$} & $5.24^{1}$ & 0 & 0.331 at & 0.025 at & $0.354-0.268^{8}$ & $0.041-0.037$ at $273-286$ \\
\hline & & & $228 \mathrm{~nm}$ & $284 \mathrm{~nm}$ & & $\mathrm{~nm}, \max \mathrm{n} / \mathrm{d}$ \\
\hline & in $44 \mathrm{mo}$ & & & & & \\
\hline & $5.26^{1}$ & -0.02 & - & - & $0.317-0.237^{7}$ & $\begin{array}{l}0.043 \text { at } 284.4 \mathrm{~nm} \text {, max } \\
\mathrm{n} / \mathrm{d}\end{array}$ \\
\hline \multicolumn{7}{|c|}{ sample $4(40513)$} \\
\hline $6.64^{1}$ & $5.31^{1}$ & 1.33 & $0.267-0.186$ & 0.017-0.014 & $3.107-2.947^{8}$ & $2.335, \lambda_{\max }=278$ \\
\hline $6.20^{1}$ & $5.36^{1}$ & 0.84 & $0.270-0.189$ & $0.021-0.016$ & $2.628-2.484^{8}$ & $1.662, \lambda_{\max }=277$ \\
\hline \multirow[t]{6}{*}{$5.68^{1}$} & $5.31^{1}$ & 0.37 & $0.283-0.200$ & $0.020-0.015$ & $2.465-2.3278$ & $1.621, \lambda_{\max }=278$ \\
\hline & in $45 \mathrm{mo}$ & & & & & \\
\hline & $5.01^{4}$ & 0.30 & - & - & $1.568-1.448^{7}$ & $1.690, \lambda_{\max }=278$ \\
\hline & in $50 \mathrm{mo}$ & & & & & \\
\hline & $5.25^{1}$ & -0.24 & - & - & $1.587-1.451^{6}$ & $1.695, \lambda_{\max }=279$ \\
\hline & $5.07^{2}$ & & & & & \\
\hline $5.43^{1}$ & $5.25^{1}$ & 0.18 & $0.295-0.211$ & $0.024-0.020$ & $2.194-2.066^{8}$ & $1.357, \lambda_{\max }=280$ \\
\hline $5.20^{1}$ & $5.15^{1}$ & 0.05 & $0.317-0.229$ & $0.042-0.043$ & $1.995-1.872^{8}$ & $1.282, \lambda_{\max }=281$ \\
\hline \multicolumn{7}{|c|}{ sample $7(30415)$} \\
\hline $6.48^{1}$ & $6.15^{1}$ & 0.33 & - & - & $0.2916-0.2028^{5}$ & $0.0321-0.0289$ at $273-$ \\
\hline & & & & & & $\begin{array}{l}286 \mathrm{~nm}, \\
\max n / d\end{array}$ \\
\hline \multirow[t]{5}{*}{$6.03^{1}$} & $6.13^{1}$ & -0.10 & - & - & $0.2663-0.1784^{5}$ & $0.0130-0.0158$ at $273-$ \\
\hline & & & & & & $286 \mathrm{~nm}$ \\
\hline & & & & & & $\max n / d$ \\
\hline & in $22 \mathrm{mo}$ & & & & & \\
\hline & $5.61^{4}$ & 0.52 & - & - & $0.324-0.254^{7}$ & $0.073, \lambda_{\max }=270.5$ \\
\hline $5.73^{1}$ & $5.67^{1}$ & 0.06 & - & - & $0.2860-0.1979^{5}$ & $0.0202-0.0231$ at $273-$ \\
\hline & & & & & & $\begin{array}{l}286 \mathrm{~nm} \\
\max \mathrm{n} / \mathrm{d}\end{array}$ \\
\hline & in 26 mo & & & & & \\
\hline & $5.64^{1}$ & 0.03 & - & - & $0.349-0.266^{6}$ & $0.074-0.063$ at $273-286$ \\
\hline & $5.49^{2}$ & & & & & $\mathrm{~nm}, \max \mathrm{n} / \mathrm{d}$ \\
\hline $5.41^{1}$ & $5.47^{1}$ & -0.06 & $0.256-0.169$ & $-0.0059-$ & $0.2739-0.1855^{5}$ & $0.0050-0.0093$ at $273-$ \\
\hline & & & & -0.0029 & & $\begin{array}{l}286 \mathrm{~nm}, \\
\max \mathrm{n} / \mathrm{d}\end{array}$ \\
\hline & in $22.5 \mathrm{mo}$ & & & & & \\
\hline & $5.26^{2}$ & 0.21 & - & - & $0.374-0.291^{6}$ & $0.102, \lambda_{\max }=276$ \\
\hline $5.20^{1}$ & $5.17^{1}$ & 0.03 & $0.264-0.175$ & $0.0046-$ & $0.2954-0.2052^{5}$ & $0.0115-0.0159$ at $273-$ \\
\hline & & & & -0.0019 & & $\begin{array}{l}286 \mathrm{~nm}, \\
\max \mathrm{n} / \mathrm{d}\end{array}$ \\
\hline sample & & & & & & \\
\hline $6.44^{1}$ & $6.27^{1}$ & 0.17 & - & - & $0.2765-0.1891^{5}$ & $0.0214-0.0224$ at $273-$ \\
\hline & & & & & & $\begin{array}{l}286 \mathrm{~nm}, \\
\max \mathrm{n} / \mathrm{d}\end{array}$ \\
\hline
\end{tabular}




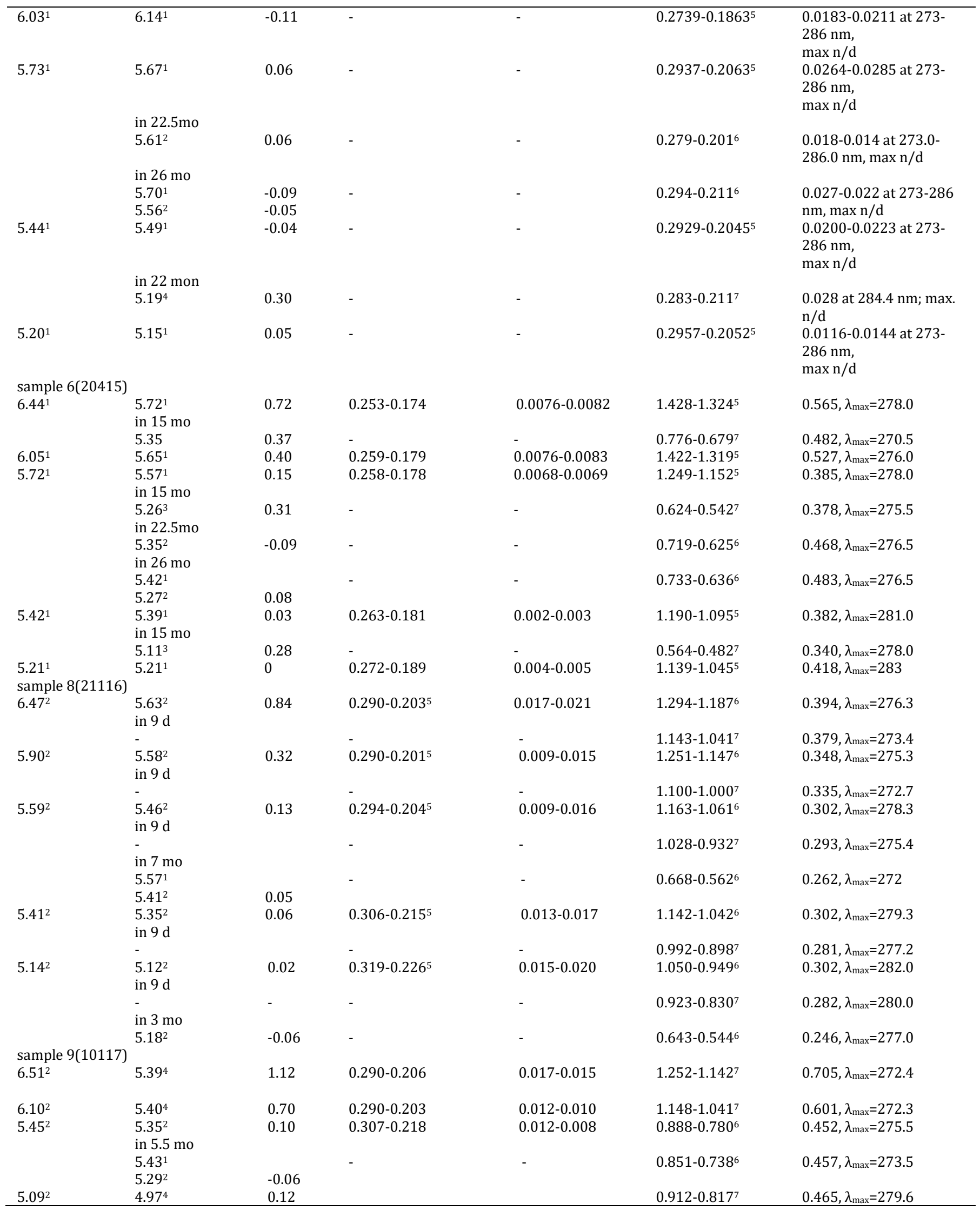

*-standard deviation (SD) is \pm 0.01 ( $\mathrm{n}=3$ measurements of $\mathrm{pH}$ of a sample before sterilization); ${ }^{* *}$-SD is \pm 0.05 for measuring $\mathrm{pH}$ after sterilization for $2-3$ containers $(n=3$ measurements of $\mathrm{pH}$ of a sample); $\max \mathrm{n} / \mathrm{d}$-absorption maximum was not detected; 1-8-these fig. identify the analytical equipment indicated in the materials and methods section. 
Currently, the main way of ensuring the sterility of PD solutions is thermal sterilization $[9,10]$. GDPs are formed during sterilization and following storage of PD solutions $[4,10]$. The British Pharmacopoeia only regulates the 5-HMF content for PD solutions containing glucose and sodium lactate or sodium hydrocarbonate. The 5-HMF content should be not more than $10 \mu \mathrm{g}$ for every $25 \mathrm{mg}$ of glucose. The content of other GDPs is not regulated by the British Pharmacopoeia [20]. However, literature data indicate the cytotoxic effect of 3,4-DGE, high concentrations of glucose and low acidic $\mathrm{pH}$ of these solutions on the renal tubular epithelial cells, peritoneal mesothelium cells, etc. $[4,10,12]$. 3,4-DGE has a maximum absorption at 228-230 $\mathrm{nm}[10,21]$. According to our unpublished studies, 5-HMF has a maximum absorption at 228 and $284 \mathrm{~nm}$. The quality of solutions for PD may be determined by simple measurements of the absorbance at 228 and $284 \mathrm{~nm}$ [10]. 3,4-DGE is considered to be a highly relevant parameter for the development and quality control of PD solutions and it enables to control sterilization regimes and storage conditions in the pharmaceutical manufacture of any solutions containing glucose $[5,6,10,21]$.

The experimental data (tables 2 and 3 ) show that the heating time of an autoclave to the sterilization temperature and the cooling time after sterilization significantly affects the absorbance of the $\mathrm{PD}$ solutions at $228 \mathrm{~nm}$ and the absorption maximum that coincides with the published data for $5 \%$ glucose solution for infusions. It was found that the continuation of the temperature action in the process of heating and cooling the autoclave leads to an increase of the absorbance at 230 and $284 \mathrm{~nm}$ [21]. The absorbance of the most solutions after sterilization was very high at 228-230 nm that is in line with work of Erixon et al. [5]. Glucose degradation in solutions containing glucose and sodium lactate is practically absent at short terms of heating and cooling an autoclave while sterilized samples are preserved sterile. The absence of glucose degradation was confirmed by the lack of changes in $\mathrm{pH}$ and absorption spectrum of laboratory batches 1(10413), 5(10415), and 7(30415) after sterilization. However, during the storage, processes of GDPs formation were observed in batch 7(30415): an insignificant $\mathrm{pH}$ change of the solutions and the presence of a low absorbance at the wavelength of maximum absorption, indicating a slight formation of 5-HMF. These data coincide with previously published results concerning a weak increase of the absorbance of the solution sterilized by sterile filtration at 228 and $284 \mathrm{~nm}$ during storage [10].
The results of the technological experiments show that the GDPs content can be reduced if the heating and cooling times of an autoclave for each loading are adjusted. The weight of the containers is reduced in $0,046-0,138 \%$ after the thermal sterilization of laboratory batch number $8(21116)$, which is explained by the evaporation of water through the walls of PVC containers.

The results of a random stability study indicate a significant decrease in the absorbance at $228-230 \mathrm{~nm}$ in most samples during storage after sterilization which is mainly explained by a decrease in the 3,4-DGE content, followed by a gradual slight increase in the absorbance. The obtained results are in agreement with published data for a $50 \%$ glucose solution with $\mathrm{pH} 3.2$ and a solution containing glucose $1.5 \%$ and lactate $35 \mathrm{mmol} / \mathrm{l}[5,6,10]$. Erixon et al. reported that 3,4-DGE is converted into 3-DG, 5-HMF, later degradation products or other unidentified compounds during storage $[5,6]$. Among degradation products of 5-HMF may be levulinic acid $\left(\lambda_{\max }=265-266 \mathrm{~nm}\right)$, acetylacrylic acid, 5hydroxymethyl-2-furan carboxylic acid $\left(\lambda_{\max }=247 \mathrm{~nm}\right)$, and 2,5furan dicarboxylic acid $\left(\lambda_{\max }=259 \mathrm{~nm}\right)[21,22]$. During storage in some samples, an increase in the absorbance at the maximum occurs, indicating an increase in the 5-HMF content, while in the solutions of laboratory batch $8(21116)$, the absorbance at the absorption maximum reduced, indicating a decrease in the 5-HMF content. These data confirm a previous assumption that a decrease in the 3,4-DGE content may be accompanied by an increase in the concentration of 5-HMF or its decrease due to latter degradation $[5,10]$.

In all the solutions, with exception of laboratory batches 1(10413) and 5(10415), there is a significant decrease in $\mathrm{pH}$ after sterilization and an insignificant decrease in $\mathrm{pH}$ during storage, indicating the formation of low molecular weight acids after sterilization and, respectively, slight glucose degradation with forming acidic GDPs during storage. Taking into consideration the complete uncertainty of the analysis for $\mathrm{pH}$ measurements in various laboratories \pm 0.15 $\mathrm{pH}$ units [23], it is advisable to conduct stability studies at the same $\mathrm{pH}$-meter. In the absence of such an opportunity and the necessity to conduct research at different pH-meters, the conclusions about glucose degradation should be made taking into account the complete uncertainty of the $\mathrm{pH}$ analysis. $\mathrm{pH}$ of the developed PD solutions after sterilization and during storage met the requirements of the monograph of the British Pharmacopeia for PD solutions (5.0-6.5).

Table 4: Quality parameters of the tested solutions and viability of kidney cells in their presence

\begin{tabular}{|c|c|c|c|c|c|c|c|c|c|c|}
\hline \multicolumn{11}{|l|}{ Number of samples } \\
\hline index & $\mathbf{0}$ & $1(10413)$ & $2(20413)$ & $3(30513)$ & $4(40513)$ & $5(10415)$ & $6(20415)$ & $7(30415)$ & $\begin{array}{l}8(211 \\
16) \\
\end{array}$ & $\begin{array}{l}9(101 \\
7) \\
\end{array}$ \\
\hline $\begin{array}{l}\mathrm{pH} \text { before sterilization, } \\
\text { mean } \pm \mathrm{SD}^{*}(\mathrm{n}=3 \text { measurements })\end{array}$ & - & $5.71 \pm 0.01$ & $5.73 \pm 0.01$ & $5.72 \pm 0.01$ & $5.68 \pm 0.01$ & $5.73 \pm 0.01$ & $5.72 \pm 0.01$ & $5.73 \pm 0.01$ & $\begin{array}{l}5.59 \pm 0 \\
.01\end{array}$ & $\begin{array}{l}5.45 \pm 0 \\
.01\end{array}$ \\
\hline $\begin{array}{l}\mathrm{pH} \text { after sterilization, mean } \pm \mathrm{SD} \\
(\mathrm{n}=3 \text { measurements at } \mathrm{pH} 150 \mathrm{M})\end{array}$ & $5.11 \pm 0.01$ & $5.77 \pm 0.01$ & $5.37 \pm 0.01$ & $5.44 \pm 0.01$ & $5.25 \pm 0.01$ & $5.70 \pm 0.01$ & $5.42 \pm 0.01$ & $5.64 \pm 0.01$ & $\begin{array}{l}5.57 \pm 0 \\
.01\end{array}$ & $\begin{array}{l}5.43 \pm 0 \\
.01\end{array}$ \\
\hline Absorbance at $\lambda=228 \mathrm{~nm}$ & 0.038 & 0.340 & 1.081 & 0.877 & 1.587 & 0.294 & 0.733 & 0.349 & 0.668 & 0.851 \\
\hline $\begin{array}{l}\text { Absorbance at absorption maximum } \\
\left(\lambda_{\max }=273-279 \mathrm{~nm}\right)\end{array}$ & $\begin{array}{l}\text { max absent, } \\
0.002 \\
\text { at } 273-286 \\
\mathrm{~nm}\end{array}$ & $\begin{array}{l}\text { max absent, } \\
0.043-0.034 \\
\text { at } 273-286 \\
\mathrm{~nm}\end{array}$ & 0.923 & 0.686 & 1.695 & $\begin{array}{l}\text { max absent, } \\
0.027-0.022 \\
\text { at 273-286 } \\
\mathrm{nm}\end{array}$ & 0.483 & $\begin{array}{l}\text { max absent, } \\
0.074-0.063 \\
\text { at } 273-286 \\
\mathrm{~nm}\end{array}$ & 0.262 & 0.457 \\
\hline $\begin{array}{l}\text { Chloride content, } \mathrm{mmol} \text {, mean } \pm \mathrm{SD} \text {, } \\
\mathrm{n}=2-4 \text { titrations }\end{array}$ & $152 \pm 0$ & $95.75 \pm 0.35$ & $94.63 \pm 0.25$ & $96.5 \pm 0$ & $94.5 \pm 0.71$ & $100.75 \pm 0.35$ & $100.17 \pm 0.29$ & $99.65 \pm 0.21$ & $\begin{array}{l}99.0 \pm 0 \\
.41\end{array}$ & $\begin{array}{l}99.75 \pm \\
0.23\end{array}$ \\
\hline $\begin{array}{l}\text { Chloride content from stated } \\
\text { amount, }(95-105 \%)\end{array}$ & 98.7 & 100.79 & 99.61 & 101.58 & 99.47 & 100.75 & 100.17 & 99.65 & 104.21 & 105.0 \\
\hline \multicolumn{11}{|c|}{ Viability of Vero cells (\%) (mean $\pm S D, n=2$ two replicates for each sample) } \\
\hline MTT test & $24.69 \pm 0.52$ & $16.08 \pm 0.58$ & $15.21 \pm 0.17$ & $12.72 \pm 0.58$ & $13.94 \pm 0.06$ & $11.86 \pm 0.29$ & $15.04 \pm 2.31$ & $13.42 \pm 0.46$ & $\begin{array}{l}14.11 \pm \\
0.46\end{array}$ & $\begin{array}{l}13.24 \pm \\
0.17\end{array}$ \\
\hline NR test & $31.79 \pm 0.20$ & $17.05 \pm 0.86$ & $18.56 \pm 1.32$ & $19.09 \pm 1.32$ & $21.59 \pm 1.97$ & $16.32 \pm 1.32$ & $16.85 \pm 0.66$ & $16.85 \pm 0.66$ & $\begin{array}{l}19.87 \pm \\
0.66\end{array}$ & $\begin{array}{l}27.25 \pm \\
1.32\end{array}$ \\
\hline SRB test & $37.44 \pm 0.21$ & $29.52 \pm 0.35$ & $31.12 \pm 0.56$ & $33.41 \pm 1.46$ & $35.08 \pm 0.35$ & $29.32 \pm 0$ & $37.58 \pm 0.07$ & $35.36 \pm 0.21$ & $\begin{array}{l}32.23 \pm \\
0.28\end{array}$ & $\begin{array}{l}31.12 \pm \\
0.14\end{array}$ \\
\hline
\end{tabular}

*-standard deviation (SD)

The above data on the development of the sterilization process indicate that optimal sterilization conditions should be established for each containers loading and nominal volume, namely the heating time of an autoclave to sterilization temperature, the time of sterilization of a product at $121^{\circ} \mathrm{C}$, the cooling time of the autoclave and cooling conditions of containers after sterilization. It is necessary to provide the lowest values of the absorbance of solutions at $228-230 \mathrm{~nm}$ and at the absorption maximum while 
maintaining the quality of the product for the sterility. According to the literature data, sterilization time of PD solutions ranges from 15 to $80 \mathrm{~min}$ at $121^{\circ} \mathrm{C}[5,9,10]$.

In vitro cell-based assay is widely employed to fast determine the cytotoxic activity of different individual compounds, mixtures of compounds, toxins, and medicinal products, including PD solutions, etc. $[7,15,17,25]$. Currently, Vero cell line is used in cytotoxicity assay $[24,25]$. Data on the cytotoxic activity of the tested solutions in the MTT, NR and SRB tests are presented in table 4 and fig. 1.

The intensity of forming formazan crystals in the cytoplasm can be judged by the level of mitochondrial activity (cell respiration), which is an indicator of functional activity and cell viability. The amount of produced formazan is proportial to the number of living cells [15]. It was found that the tested samples had the greatest negative effect on the kidney cells mitochondria in the MTT test. In this test, the cells viability was in the range of $12 \%$ to $16 \%$ compared with $25 \%$ of viability in the presence of $0.9 \%$ solution of sodium chloride. Sample 5(10415) showed the largest cytotoxic action: the number of viable Vero cells was $11.86 \% \pm 0.29 \%$.

Similarly, it was found that the tested samples had a negative effect on the permeability of the membranes and functioning of kidney cell lysosomes in the NR test. Lysosome integrity with concomitant binding NR is a highly sensitive indicator of cell viability as the dye cannot be retained when a cell dies [18]. In this test, the vitality of cells was within the range of $16 \%$ to $35 \%$. Compared with the data in the control wells, sample 5(10415) also showed the largest cytotoxic action. The number of viable cells was $16.32 \% \pm 1.32 \%$. Samples 8(21116) and 9(10117) were of the smallest cytotoxic action: $19.87 \% \pm 0.66 \%$ and $27.25 \% \pm 1.32 \%$, respectively. These data are in line with Erixon et al., who stated approximately $43 \%$ of cells growth inhibition at a dilution of a conventional PD solution with medium in the ratio of 3 to 2 in the NR test (3,4-DGE and glucose concentration were $13 \mu \mathrm{mol} / \mathrm{l}$ and $2.5 \%$, respectively) [6]. Similar data in the NR test were obtained at dilutions of 2 to 1 and 1 to 1 (65\%-95\% of the viability of Vero cells).

In SRB test it was found that the tested solutions for PD had also a negative effect on the synthesis of proteins and kidney cells ability to proliferation. In this case, the viability of the cells was within the range of $29 \%$ to $38 \%$ compared with $37 \%$ of viability in the presence of $0.9 \%$ sodium chloride solution. The largest cytotoxic action was also shown by sample 5(10415). The number of viable cells in the Vero cells was 29.32\%. Samples 4(40513) and 6(20415) showed the smallest cytotoxic action: $35.08 \% \pm 0.35 \%$ and $37.58 \% \pm 0.77 \%$, respectively.

The results of this study confirm the literature data on the cytotoxicity of PD solutions $[4,6,7,10,12,13]$. As it was stated by Li et al., limiting remesotelization took place independently on glucose concentration and finally led to apoptosis [8]. However, it is not yet known what factor or combination of these causes cytotoxicity. A relatively insignificant viability of Vero cells in the presence of isotonic sodium chloride solution can be explained, in particular, by its low $\mathrm{pH}$ (5.11).

Consequently, the results of the cytotoxicity in vitro study suggest that the cytotoxic activity of the tested solutions for PD was the highest in the MTT test and the lowest in the SRB test. The correlation between viability of the cells in the different tests was established. The value of the correlation coefficient between the viability growth in the MTT test and the increase in the $\mathrm{pH}$ of the solutions after sterilization was $r=0.31$. It characterizes this correlation between the values as weak one. The opposite correlations were found in the SRB and NR tests.

The negative correlation coefficient was established as- 0.38 between the viability reducing and the increase in the $\mathrm{pH}$ of the PD solution after sterilization in the SRB test. A weak, but significantly stronger, negative correlation $(r=-0,496)$ was also found between a reduce in the cells viability and an increase in the $\mathrm{pH}$ solutions in the NR test (at pH-meter 150M, fig. 1).

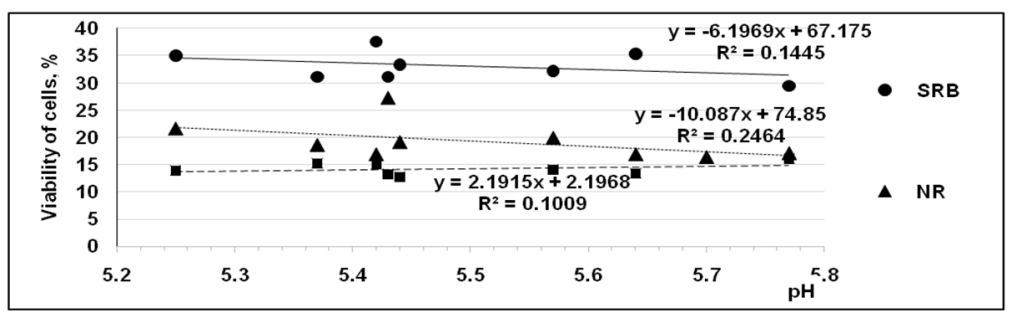

Fig. 1: Estimation of Vero cells viability depending on $\mathrm{pH}$ of the PD solutions after sterilization

The low data of cell viability are in line with published results concerning $100 \%$ of cell growth inhibition at a pH of 5.0 [7]. Data of the MTT test could be used as an additional tool of improving of formulation and/or technology of PD solutions, for instance, elevation of $\mathrm{pH}$ before and after sterilization, usage of sophisticated sterilization regimes, etc.
Comparing the cells viability correlation with using MTT and NR tests, MTT and SRB tests, respectively, negative correlation coefficients were established as- 0.473 between increasing viability in the MTT test and decreasing viability in the NR test, and- 0.27 between increasing viability in the MTT test and decreasing viability in the SRB test, respectively (fig. 2).

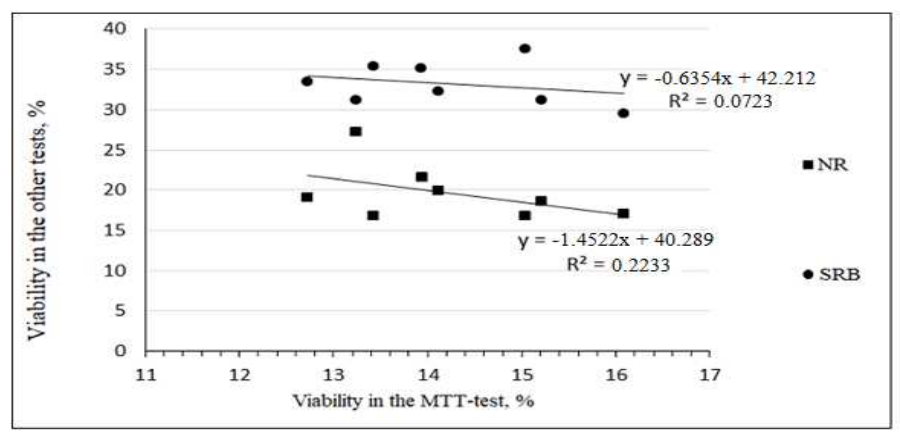

Fig. 2: Correlation of the MTT test with other viability tests 
These correlations can indicate the different cytotoxicity mechanisms and properties of these three tests-inhibition of mitochondrial activity and disturbance of mitochondrial integrity in the MTT test, disturbance of membranes integrity and lysosomes function in the NR test, pH-dependence of NR test, less $\mathrm{pH}$ dependence of SRB test, and disturbance of protein synthesis, etc. Comparing connection of cell viability in the NR test with MTT and
SRB tests, negative correlation coefficients were also established:0.288 between increasing in the viability in the NR test and decreasing in the viability in the SRB test and- 0.473 between increasing viability in the NR test and decreasing viability in the MTT test, respectively, (fig. 3) that also confirms the different mechanisms of cytotoxicity which are determined with these three tests.

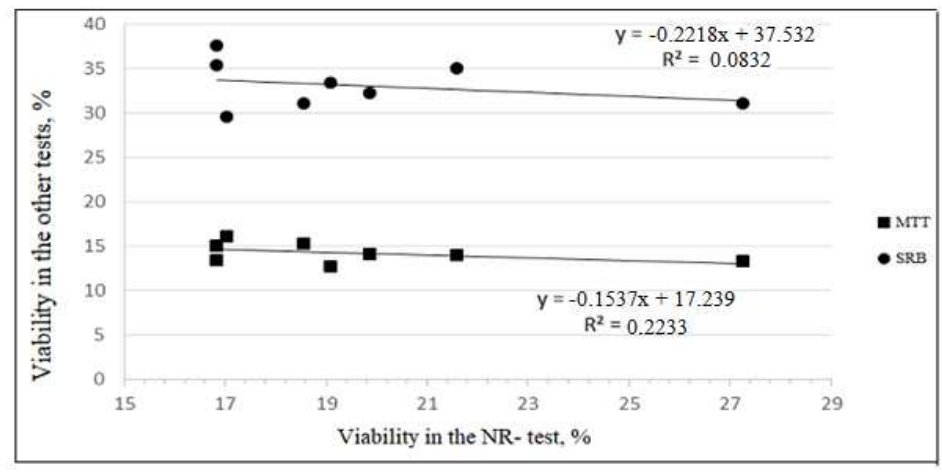

Fig. 3: Correlation of the NR test with other viability tests

All the laboratory batches met the requirements of the monograph for PD solutions of the British Pharmacopeia for the indexes of $\mathrm{pH}$ $(5.0-6.5)$ and chloride content $(95 \%-105 \%$ from the stated amount) (tables 3 and 4).

\section{CONCLUSION}

The results of complex studies of the PD solutions containing glucose and sodium lactate in single-chamber containers are presented, including selective stability study during storage. The effects of heating the autoclave to the sterilization temperature and its cooling on the formation of 3,4-DGE and 5-HMF are shown. It is determined that the larger the time indicators of the autoclave, the more are the 3,4-DGE and 5-HMF contents. There is a decrease in the absorbance at 228-230 nm during storage with a subsequent gradual increase in the absorbance, indicating a significant reducing in the 3,4-DGE content and a slight it's increasing during storage. During storage an increase in the absorbance at the maximum occurs in part of the tested samples, indicating an increase in the content of 5-HMF, while in other samples the absorbance at the wavelength of maximum absorption is reduced indicating a decrease in the content of 5-HMF. There is a decrease in the $\mathrm{pH}$ of the solutions in most samples after sterilization and during storage. An evaluation of the cytotoxic activity of the tested solutions was conducted by determining the viability of the Vero cells using three tests in vitro. The largest cytotoxic activity of the tested PD solutions and isotonic solution of sodium chloride was in the MTT test and the lowest one is observed in the SRB test. Weak correlations between the three tests were established that may indicate quite different mechanisms of cytotoxicity determined by each of these tests.

\section{ACKNOWLEDGMENT}

Authors are thankful to Nataliia Dmytrukha for her help in performing analysis of viability studies.

Co-author Nataliia Hudz is grateful to the International Visegrad Fund (contract No. 51700107) for providing a scholarship for studies related to solutions for dialysis therapy.

\section{AUTHORS CONTRIBUTIONS}

Hudz N.-70\% (research concept and design, writing the article, data analysis and interpretation), the rest authors have an equal contribution (critical revision and final approval of the article).

\section{CONFLICT OF INTERESTS}

The authors declare that there are no conflicts of interest

\section{REFERENCES}

1. Elsayed AS, Azab AE. Correlation between chronic kidney diseases and hematological data in Sabratha hospital in Libya. Asian J Pharm Clin Res 2017;10:291-6.

2. Murali M, Sathyanarayana D, Muthusethupathy M. Assessment of quality of life in chronic kidney disease patients using the kidney disease quality of life-short form ${ }^{\text {tm }}$ questionnaire in Indian population: a community-based study. Asian J Pharm Clin Res 2015;8:271-4.

3. Kaur G, Prinja S, Ramachandran R, Malhotra P, Lal Gupta K, Jha V. Cost of hemodialysis in a public sector tertiary hospital of India. Clin Kidney J 2018;1-8. https://doi.org/10.1093/ ckj/sfx152.

4. Justo P, Sanz AB, Sanz AB, Egido J, Ortiz A. 3,4dideoxyglucosone-3-ene induces apoptosis in renal tubular epithelial cells. Diabetes 2005;54:2424-9.

5. Erixon $M$, Lindén $T$, Kjellstrand $P$, Carlsson 0 , Ernebrant $M$, Forsbäck G, et al. PD fluids contain high concentrations of cytotoxic GDPs directly after sterilization. Peritoneal Dial Int 2004;4:392-8.

6. Erixon $\mathrm{M}$, Wieslander $\mathrm{A}$, Lindén $\mathrm{T}$, Carlsson $\mathrm{O}$, Forsbäck $\mathrm{G}$, Svensson E, et al. Take care in how you store your PD fluids: actual temperature determines the balance between reactive and non-reactive GDPs. Peritoneal Dial Int 2005;25:583-90.

7. Diaz Buxo J, Sawin DA, Himmele R. PD solutions: new and old. Dial Transplant 2011;40:356-61.

8. Li P, Kit-Chung J, Mcintyre CW. Inflammation and peritoneal dialysis. Semin Nephrol 2017;37 Suppl 1:54-65.

9. Hanrahan CT. The challenges of heat sterilization of peritoneal dialysis solutions: is there an alternative? Adv Peritoneal Dial 2012;28:126-30.

10. Kjellstrand P, Erixon M, Wieslander A, Lindén T, Martinson E. Temperature: the single most important factor for degradation of glucose fluids during storage. Peritoneal Dial Int 2004;24:385-91.

11. Distler L, Georgieva A, Kenkel I, Huppert J, Pischetsrieder M. Structure-and concentration-specific assessment of the physiological reactivity of $\alpha$-dicarbonyl glucose degradation products in peritoneal dialysis fluids. Chem Res Toxicol 2014;27:1421-30.

12. Santamaria B, Ucero AC, Reyero A, Selgas R, Ruiz-Ortega M, Catalan $\mathrm{M}$, et al. 3,4-Dideoxyglucosone-3-ene as a mediator of peritoneal demesothelization. Nephrol Dial Transplant 2008;23:3307-15.

13. Le Poole CY, Welten AG, Ter Wee Pm, Paauw NJ, Djorai AN, Valentijn RM, et al. A dialysis regimen low in glucose and glucose degradation products results in increased cancer antigen 125 and peritoneal activation. Peritoneal Dial Int 2012;32:305-15. 
14. Blake PG, Jain AK, Yochann S. Biocompatible peritoneal dialysis solutions: many questions but few answers. Kidney Int 2013;84:865-6.

15. Florento L, Matias R, Tuaño E, Santiago K, dela Cruz F, Tuazon A. Comparison of cytotoxic activity of anticancer drugs against various human tumor cell lines using in vitro cell-based approach. Int J Biomed Sci 2012;8 Suppl 1:76-80.

16. Shabrina M, Suniarti DF, Amir LR, Idrus E. Toxicity analysis of RGD-chitosan from shrimp shell scaffold membranes toward human dental pulp cells. Int J Appl Pharm 2017;9 Suppl 1:13-6.

17. Nagalakshmik K, Suiathas S. Nanoencapsulation augments release efficacy and glucose tolerance of 14-deoxy, 11,12didehydroandrographolide loaded polycaprolactone nanoparticles in streptozotocin-nicotinamide induced type 2 diabetes. Int J Appl Pharm 2017;9 Suppl 6:51-3.

18. Repetto G, del Peso A, Zurita JL. Neutral red uptake assay for the estimation of cell viability/cytotoxicity. Nat Protoc 2008;3:1125-31.

19. Bühl A, Zofel P. SPSS Version 10. Einführung in die moderne Datenanalyseunte Windows, 7, uberarbeitete und erweiterte Auflage, DiaSoft; 2005.
20. British Pharmacopoeia. London; British Pharmacopoeia Commission; 2009.

21. Tereshkina OI, Isayeva IV. Investigation of thermal degradation products of glucose in model solutions. Pharm 1991;6:24-8.

22. Zhang J, Li J, Tang Y, Xue G. Rapid method for the determination of 5-hydroxymethylfurfural and levulinic acid using a doublewavelenght UV spectroscopy. Sci World J 2013;1-6. http://dx.doi.org/10.1155/2013/506329

23. Sur SV, Arhypova NN, Zvolynska NN. Rezul'tati chetvertogo raunda programmi proffesional'nogo testirovaniya laboratorii v sisteme Gosudarstvennoi inspektsii po kontrolyu kachestva lekarstvennih sredstv MZ Ukraini. 2. Otsenka rezul'tatov opredeleniya soderzhaniya glyukozi i izmereniya $\mathrm{rN} \mathrm{v}$ testovih obraztsah rastvora glyukozi 5\% dlya infuzii. Provizor 2005;8:29-32.

24. Akter R, Uddin SJ, Tiralongo J, Grice ID, Tiralongo E. A new cytotoxic steroidal glycoalkaloid from the methanol extract of Blumea lacera leaves. J Pharm Pharm Sci 2015;18 Suppl 4:616-33.

25. Ammerman NC, Beier-Sexton M, Azad AF. Growth and maintenance of vero cell lines. Curr Protoc Microbiol 2008. 